\title{
Esensi Interaksi Visual dalam Dunia Facebook yang Virtual
}

\author{
Noval Sufriyanto Talani \\ Program Studi Ilmu Komunikasi Fakultas Ilmu Sosial Universitas Negeri Gorontalo
}

\begin{abstract}
This article discusses the phenomenon of interaction on Facebook. This study used a subjective approach with a qualitative research method through the analysis of the phenomenology and symbolic interaction. The study was conducted to determine the essential meaning of symbolic interaction that occurs in the world of Facebook. Through in-depth interviews of 10 people found that Facebook users are interchangeable symbols emoticons users to interact on Facebook has a contextual meaning. At different users' of a symbol can have different meanings so the meaning is no longer unconventional, but personal. This is caused by the user freedom in using or producing personal emoticon symbols as an expression of nonverbal cues. Essentially, the interaction on Facebook is the visual interaction. Through visual, users' can display a variety of actions on Facebook including symbolic impression management. Impression management on Facebook is heavily influenced intentional relationship between physical self as a subject in the real world and themselves become symbolic objects in the virtual world. This relationship is illustrated by a model of interaction and symbolic impression management model in the virtual world of Facebook.
\end{abstract}

Key Words : Facebook, emoticons, relation, intentional, visual interaction

\begin{abstract}
Abstrak
Artikel ini membahas fenomena interaksi di Facebook. Penelitian ini menggunakan pendekatan subjektif dengan metode penelitian kualitatif melalui perangkat analisis fenomenologi dan interaksi simbolik. Penelitian dilakukan untuk mengetahui makna esensial dari interaksi simbolik yang terjadi di dunia Facebook. Melalui wawancara mendalam terhadap 10 orang pengguna Facebook ditemukan bahwa simbol emotikon yang dipertukarkan pengguna dalam berinteraksi di Facebook memiliki makna kontekstual. Pada pengguna yang berbeda sebuah simbol dapat memiliki makna yang berbeda pula sehingga makna tidak lagi bersifat konvensional, melainkan bersifat pribadi. Hal ini disebabkan oleh kebebasan pengguna dalam menggunakan atau memproduksi simbol emotikon pribadi sebagai ekspresi dari isyarat nonverbal. Secara esensial, interaksi di Facebook merupakan interaksi visual. Melalui visual, pengguna dapat menampilkan berbagai tindakannya di Facebook termasuk pengelolaan kesan secara simbolik. Pengelolaan kesan di Facebook sangat dipengaruhi relasi intensional antara diri fisik sebagai subjek di dunia nyata dan diri simbolik yang menjadi objek di dunia virtual. Relasi ini digambarkan melalui model interaksi maupun model pengelolaan kesan simbolik di dunia virtual Facebook.
\end{abstract}

Kata Kunci: Facebook, emotikon, relasi, intensional, interaksi visual 


\section{Pendahuluan}

Argumen Don Ihde (Lim, 2008: 78) tentang kehadiran teknologi dalam kehidupan manusia yang diterima sebagai suatu hal yang wajar dan tanpa mempermasalahkannya sangat relevan dengan fenomena teknologi digital saat ini. Bahkan bisa dikatakan manusia sangat bergantung pada teknologi. Perkembangan teknologi digital mutakhir seolah menjadi fakta dari ketergantungan manusia pada teknologi. Kehadiran Internet adalah contoh konkret dari penggunaan teknologi yang kehadirannya tak dipermasalahkan, meskipun tidak sedikit dampak buruk yang ditimbulkan.

Sebagai dunia virtual atau juga disebut cyberspace, Internet menjadi kehidupan kedua (second life) masyarakat kontemporer (Zhapiris dan Ang, 2010: 205; Mitra, 2010: 48). Yang dimaksud kehidupan kedua, karena melalui rekayasa teknologi digital, substitusi ruang-ruang sosial di dunia nyata diwujudkan dalam bentuk artifisial. Sehingga wujud artifisial dari ruang-ruang sosial menjadi semacam simulasi sosial, di mana pelbagai simulasi itu menemukan tempat hidupnya di ruang yang disebut cyberspace. Hasil penelitian Sosiawan (2001) misalnya, menemukan fakta bahwa Internet menjadi substitusi dari bentuk komunikasi antarpribadi maupun komunikasi massa dengan membawa pesan yang beraneka rupa dalam bentuk teks, grafis, suara, dan citra bergerak. Dalam ruang sosial di dunia nyata, komunikasi antarpribadi maupun komunikasi massa terjadi di ruang berbeda. Tetapi, melalui Internet kedua bentuk komunikasi itu dapat dilakukan dalam satu ruang.

Kehadiran sosial media seperti Facebook, Twitter, MySpace, YouTube, atau Instagram, lebih mengukuhkan lagi bahwa manusia tak bisa lepas dari teknologi. Sebagai makhluk sosial, manusia butuh berinteraksi dengan orang lain. Melalui interaksi manusia dapat berhubungan, berkolaborasi, dan menunjukkan eksistensi dirinya dalam ruang sosial yang melingkupinya. Sosial media mampu memenuhi kebutuhan itu, di mana seseorang dapat berinteraksi dengan orang lain tanpa dibatasi ruang dan waktu. Merujuk pada Mitra, situs jejaring sosial MySpace, Facebook, dan Twitter telah menjadi sebuah fenomena sosial, memperkenankan orang-orang terhubung dan membangun hubungan jarak jauh (dan kadang kala melupakan) teman dan kolega (Mitra, 2010:48).

Meskipun Mitra menyebut pengguna sosial media kadang kala melupakan teman dan kolega, pada kenyataannya banyak orang memiliki profil di sosial media. Di antara sosial media yang terus berkembang, Facebook merupakan sosial media yang sangat fenomenal. Penggunanya mencapai hampir satu miliar orang hanya dalam waktu kurang dari enam tahun sejak diluncurkan untuk umum pada September 2006 (data per Maret 2012 dalam Talani, 2013: 2). Facebook juga didukung oleh fitur-fitur interaktif dengan kecepatan feedback yang instan seperti fitur like, comment, share, video call, atau chat room. Tak heran jika dalam penelitiannya, Muntaha (dalam Hamid dan Budianto, 2011: 504) menemukan bahwa Facebook menjadi salah satu ruang komunikasi keluarga nettie (nettie family) dengan pola cepat-sederhana. Selain fitur-fitur di atas, menurut Dave Awl (2011: 2), fitur untuk membuat grup dan page yang dapat menghubungkan orang-orang dengan kepentingan sama serta menyebarkan berita mengenai proyek-proyek kreatif atau bisnis yang membuat miliaran orang menggunakan Facebook.

Dalam konsep CMC (computer mediated communication), fitur-fitur tersebut berbasis graphical user interface (GUI). Konstruksi GUI tidak hanya 
membuat CMC lebih user friendly, ungkap Thurlow dkk. (2004: 225), tetapi juga mengubah bagaimana cara kita berkomunikasi di Web. GUI membantu pengguna menghindari mempelajari bahasa perintah yang kompleks. Imaji, foto, dan emotikon adalah peningkatan umum, seperti menyerupai karakteristik visual dasar sebagai petunjuk dan mudah dikenali. Yang menarik adalah melalui fitur-fitur itu pengguna melakukan interaksi secara simbolik. Dalam interaksi, pengguna Facebook (facebook useer) bukan saja menampilkan pesan verbal, melainkan juga menampilkan pesan nonverbal yang mewakili ekspresi penggunanya.

Untuk menampilkan ekspresi, pengguna menggunakan emotikon sebagai simbol umum yang telah tersedia di Facebook atau memproduksi simbol sendiri. Penggunaan emotikon umum menunjukkan bahwa simbol itu memiliki makna konvensional. Sedangkan penggunaan simbol emotikon yang diproduksi sendiri akan membawa pada makna yang relatif, makna bergantung pada pengguna simbol itu sendiri. Nellis mencontohkan penggunaan akronim atau simbol emotikon sebagai substitusi isyarat nonverbal. Misalanya, penggunaan akronim ROLF (rolling on the floor laughing) atau simbol emotikon :) yang bermakna bahagia sebagai substitusi untuk isyarat nonverbal (Baldwin $\mathrm{dkk}$, 2004: 249). Selanjutnya Nellis menggambarkan perbedaan penggunaan emotikon yang umum dengan akronim atau singkatan umum yang biasa digunakan dalam interaksi di dunia maya seperti terlihat pada gambar berikut:

Tabel 1. Common Meanings of CMC Emoticons

\begin{tabular}{llll}
\hline$:)$ & Happy & $;)$ & Winking \\
$: D$ & Laughing & $:($ & Unhappy \\
$: /$ & Skeptical, uncertain & $>:($ & Angry \\
$: P$ & Sticking tongue out, so there, & $\%-)$ & Confused \\
$:>$ & disgusted & $;($ & Crying \\
$8)$ & Sarcastic & $:^{*}$ & Kiss \\
$: O$ & Wears glasses, nearsighted & $(($ insert & Hugging \\
& Yelling, shocked & name) $))$ & someone \\
\hline
\end{tabular}

Tabel 2. Common CMC Acronyms

\begin{tabular}{|c|c|c|c|}
\hline LOL & Laughing Out Loud & $\mathrm{J} / \mathrm{K}$ & Just Kidding \\
\hline ROFL & Rolling On the Floor Laughing & BTW & By The Way \\
\hline IMO & In My Opinion & RL & Real Life \\
\hline IMHO & In My Humble Opinion & VL & Virtual Life \\
\hline JMHO & Just My Humble Opinion & $\mathrm{OOC}$ & Out \\
\hline AFAIK & As For As I Know & OT & Character \\
\hline OMG & Oh My God & L8R & Off Topic \\
\hline$<\mathrm{g}>$ & Grin & BRB & Later \\
\hline$<\operatorname{vbg}>$ & Very big grin & $\mathrm{BFN}$ & Be Right Back \\
\hline$<$ veg $>$ & Very evil grin & & Bye For Now \\
\hline
\end{tabular}

Note: Meaning can vary with specific users. 
Meskipun terdapat simbol-simbol CMC yang memiliki makna umum seperti gambar di atas, tetapi tidak menutup kemungkinan terdapat perubahan makna pada pengguna tertentu seperti catatan Nellis. Perubahan makna simbol yang digunakan dalam interaksi di Facebook bergantung pada konteks penggunanya. Sehingga makna simbol bersifat kontekstual dan otonom pada pengguna tertentu. Dari perspektif interaksi simbolik, perubahan atau perbedaan makna dan simbol menunjukkan kemampuan manusia dalam "mengubah arti dan simbol yang mereka gunakan dalam tindakan dan interaksi berdasarkan penafsiran mereka terhadap situasi” (Ritzer dan Goodman, 2008:289). Simbol yang digunakan dan makna yang diberikan facebook user merupakan bentuk interpretasi terhadap suatu situasi yang mereka alami. Selain memiliki makna simbolik, penggunaan emotikon dalam interaksi di Facebook dapat pula membangun kesan simbolik bagi penggunanya.

Berdasarkan paparan di atas, penelitian ini menelaah makna dan pemahaman kesan facebook user terhadap simbol-simbol yang mereka pertukarkan dalam interaksi di Facebook dari perspektif mereka sendiri. Tujuan penelitian ini untuk mengetahui makna esensial dari interaksi simbolik yang terjadi di dunia virtual (Facebook) dengan mengungkap makna dan kesan simbolik dari simbol-simbol emotikon yang digunakan facebook user dalam berinteraksi, menggambarkan model interaksi dan model pengelolaan kesan simbolik di Facebook.

\section{Metode Penelitian}

Berdasarkan tujuan di atas, penelitian ini termasuk penelitian subjektif. Sebab, pencarian makna dan kesan simbolik didasarkan pada deskripsi verbal para pengguna Facebook (facebookers) sesuai interpretasinya terhadap fenomena (pertukaran simbol dalam interaksi) yang mereka alami. Pertukaran simbol oleh facebookers tidak terlepas dari kesadaran mereka menggunakan atau memproduksi simbol sebagai sarana mengungkapkan ide dan ekspresinya dalam interaksi.

Kesadaran adalah bagian subjektif dari dunia, sedangkan hal-hal yang bersifat materil dianggap sebagai bagian objektif dari dunia. Dan persentuhan keduanya (sisi objektif dan sisi subjektif) disebut pengalaman (Boeree, 2009: 372). Pengalaman facebokers dalam mempertukarkan (memproduksi, menggunakan, atau memaknai) simbol yang menjadi fokus penelitian ini, maka fenomenologi dan interaksi simbolik digunakan sebagai perspektif sekaligus metode analisisnya. Fenomenologi "mengasumsikan dunia sosial dan realitas sebagai proyeksi kesadaran individu, suatu tindakan imajinasi kreatif dan kondisi intersubjektif" (Mulyana, 2008: 48). Dalam pandangan fenomenologi instrumensi (hubungan manusia-alat teknologi-dunia), persepsi dan kebertubuhan yang terlibat dalam pengalaman manusia merupakan kajian fenomenologi (Lim, 2008: 78). Pertukaran simbol di Facebook menjadi realitas dalam dunia virtual dan memproyeksikan suatu tindakan melalui kesadaran penggunanya serta makna dan kesan menjadi makna intersubjektif dari intensionalitas diri fisik dan diri virtual.

Teknik pengumpulan data dilakukan melalui pengamatan dan wawancara mendalam terhadap sepuluh orang pengguna Facebook. Pemilihan informan dilakukan secara snow ball sampling. Di mana peneliti mewawancarai seorang informan, lalu dari informan itu berkembangan menjadi sepuluh orang. Jumlah ini sesuai dengan batas minimal 
partisipan dalam penelitian fenomenologi sebagaimana ditulis Creswell (1998: 65). Di samping itu, yang terpenting ialah kesediaan informan terlibat selama penelitian berlangsung serta mau menceritakan kembali pengalamannya sebagai pengguna Facebook yang mempertukarkan berbagai simbol dalam interaksinya (Kuswarno, 2009: 60). Jadi, jumlah informan dalam penelitian ini memenuhi jumlah minimal dalam penelitian fenomenologi dan para informan bersedia terlibat selama penelitian berlangsung serta mau menceritakan pengalaman mereka berinteraksi di Facebook.

\section{Hasil dan Pembahasan}

\section{Makna dan Kesan Simbolik}

Seluruh aktivitas di Facebook
termasuk interaksi para penggunanya
dilakukan secara simbolik. Berbagai
simbol yang digunakan dalam interaksi
berfungsi sebagai representasi suatu
tindakan. Secara khusus, simbol-simbol
ekspresi banyak digunakan para
facebookers secara bebas untuk menun-
jukkan respon (perasaan dan ekspresi).
Sebagai bagian dari "masyarakat" simbolik
yang tercipta dari moda komunikasi padat teknologi (lihat Siregar, 2006: 82). Dari hasil pengamatan, para facebookers informan lebih banyak menggunakan emotikon dibandingkan dengan akronim.

Setiap informan memiliki simbol khusus yang sering ia gunakan untuk mengungkapkan ekspresinya. Penafsiran informan terhadap simbol-simbol emotikon yang mereka pertukarkan menghasilkan makna yang beragam. Namun demikian, para facebookers menafsirkan simbol emotikan :) bermakna "senyum" dan kesan simboliknya "kalem," "ramah," "ceria," "bahagia," "mengiyakan," dan "baik." Kesamaan makna pada simbol emotikon (titik dua balas kurung) :) disebut dengan simbol signifikan (significant symbol) seperti ungkapan Mead (dalam Ardianto dan Q-Anees, 2007: 136). Sebuah simbol menjadi signifikan jika simbol tersebut memiliki kesamaan makna dan berlaku pada suatu masyarakat. Hal ini berarti, makna atau ekspresi "senyum" untuk simbol emotikon (titik dua balas kurung) :) menjadi konvensi yang disepakati dalam masyarakat virtual. Secara ringkas, makna dan kesan simbolik dari berbagai simbol emotikon yang digunakan informan dalam interaksinya di Facebook disajikan melalui tabel 3. 


\section{Tabel 3. Makna dan Kesan Simbol Emotikon}

\begin{tabular}{|c|c|c|}
\hline Simbol & Arti/Makna & Kesan \\
\hline$\wedge n^{\wedge}$ & $\begin{array}{l}\text { Hehe, tertawa, senyum, senang, ramah, } \\
\text { tertawa }\end{array}$ & $\begin{array}{l}\text { Lucu, senang, ceria, polos, } \\
\text { menyenangkan, gembira }\end{array}$ \\
\hline$\wedge \wedge$ & Makasih..hehehe, senyum, senang, & $\begin{array}{l}\text { Hangat, ramah, ceria, bahagia, polos, } \\
\text { baik }\end{array}$ \\
\hline$>.<$ & $\begin{array}{l}\text { Whaa.. iyah, memejamkan mata, senyum } \\
\text { malu-malu, gemes, aduh, senang }\end{array}$ & $\begin{array}{l}\text { Lucu, malu-malu, lucu, kepergok, gemes, } \\
\text { ceria }\end{array}$ \\
\hline $\mathrm{XD}$ & $\begin{array}{l}\text { Ketawa ngakak, memejamkan mata sambil } \\
\text { tertawa, tertawa, senang, tertawa lebar, } \\
\text { nyengir, senyum, gembira }\end{array}$ & $\begin{array}{l}\text { Tertawa total, lucu, ceria, bodor, } \\
\text { menertawakan, supel, bercanda }\end{array}$ \\
\hline$; \mathrm{p}$ & $\begin{array}{l}\text { Ngeledek, menjulurkan lidah, senang, melet, } \\
\text { ngejek }\end{array}$ & $\begin{array}{l}\text { Genit, iseng, meledek, lucu, boong, } \\
\text { bercanda, kesal suka }\end{array}$ \\
\hline$=.="$ & $\begin{array}{l}\text { Malesin..geje dah, memejamkan mata, diam, } \\
\text { keberatan, heran, berpikir, tidur, mengerutkan } \\
\text { wajah, kesal }\end{array}$ & $\begin{array}{l}\text { Nggak penting banget!, capedeh, murung, } \\
\text { lagi tersingung, lucu, galau, malas, heran, } \\
\text { ketus }\end{array}$ \\
\hline :D & $\begin{array}{l}\text { Tertawa lebar, senyum, tertawa, senang, } \\
\text { senyum lebar, menganga }\end{array}$ & $\begin{array}{l}\text { Terhibur, ramah, ceria, seneng, lucu, } \\
\text { senang }\end{array}$ \\
\hline$>.<\mathrm{d}$ & $\begin{array}{l}\text { Oke..sip..mantap, memberi jempol, senyum } \\
\text { malu, memuji, menyukai }\end{array}$ & $\begin{array}{l}\text { Lucu, tanda oke, penghargaan, hebat, } \\
\text { ramah }\end{array}$ \\
\hline $\mathrm{xp}$ & $\begin{array}{l}\text { Ngeledek, menjulurkan lidah sambil } \\
\text { memejamkan mata, menjulurkan lidah, senang, } \\
\text { melet, sipit, }\end{array}$ & $\begin{array}{l}\text { Ngajak rebut, lucu, meledek, jail, lucu, } \\
\text { kegencet, bercanda, kesal, ceria }\end{array}$ \\
\hline$\hat{-} \wedge$ & Senyum, senyum sipit, bahagia, senang, & $\begin{array}{l}\text { Manis, ramah, ceria, bahagia, senang } \\
\text { pada.., tersipu-sipu bahagia, ceria, }\end{array}$ \\
\hline :] & Eghhh, senyum, datar, senyum lebar, & $\begin{array}{l}\text { Nggak bisa ngomong, ceria, lagi } \\
\text { tersinggung, ramah, dipaksakan, } \\
\text { mengangguk, baik }\end{array}$ \\
\hline$\wedge \wedge v "$ & Damai..peace, piss, senyum, senyum memuji & $\begin{array}{l}\text { Menghidari masalah, iseng, tanda peace, } \\
\text { lucu, minta maaf, hebat, ramah }\end{array}$ \\
\hline :) & Senyum & $\begin{array}{l}\text { Kalem, ramah, ceria, bahagia, } \\
\text { mengiyakan, baik }\end{array}$ \\
\hline$\backslash\left(\wedge 0^{\wedge}\right) /$ & $\begin{array}{l}\text { Horee, mengangkat tangan sambil tertawa, } \\
\text { tertawa, horeee, gembira, senang, bersorak }\end{array}$ & $\begin{array}{l}\text { Semangat, ceria, senengnya, lucu, } \\
\text { gembira, riang, bahagia }\end{array}$ \\
\hline$(\wedge, \wedge)$ & $\begin{array}{l}\text { Senyum, gembira, kecele, senyum manyun, } \\
\text { senang }\end{array}$ & $\begin{array}{l}\text { Tanda terimaksih, lucu, bahagia, } \\
\text { bercanda, ceria, gembira }\end{array}$ \\
\hline ;D & $\begin{array}{l}\text { Ketawa, tersenyum lebar, tertawa, menganga, } \\
\text { senang }\end{array}$ & $\begin{array}{l}\text { Genit, senang, ceria, bahagia, lucu, ada } \\
\text { sesuatu, senang suka, gembira }\end{array}$ \\
\hline$b^{\wedge \wedge} d$ & $\begin{array}{l}\text { Mantap-mantap..oke, dual jempol, senyum, } \\
\text { angkat jempol, good, hebat, good job, menyukai }\end{array}$ & $\begin{array}{l}\text { Penegas..mengerti total, salut, tanda oke, } \\
\text { good, penghargaan, memuji, suka, } \\
\text { komentar baik, ramah }\end{array}$ \\
\hline ;) & $\begin{array}{l}\text { Senyum, senyum sambil main mata, sipit } \\
\text { senyum, kedip mata }\end{array}$ & $\begin{array}{l}\text { Genit, ceria, bahagia, lucu, penuh arti, } \\
\text { gembira, suka, }\end{array}$ \\
\hline$:^{*}$ & Kecupan..sun, cium, siul, kiss & $\begin{array}{l}\text { Manis, menggoda, sayang, cuek, cinta, } \\
\text { genit }\end{array}$ \\
\hline B) & $\begin{array}{l}\text { Ketawa cool, kacamata senyum, bergaya keren, } \\
\text { pake kacamata, senyum, cool }\end{array}$ & $\begin{array}{l}\text { Keren, sok tau, keren, cool, lucu, gurauan, } \\
\text { gaya }\end{array}$ \\
\hline$\wedge \wedge d$ & $\begin{array}{l}\text { Sip, jempol, senyum, senyum kasih jempol, } \\
\text { menyukai }\end{array}$ & $\begin{array}{l}\text { Memperhatikan, salut, tanda oke, good, } \\
\text { lucu, memuji, keren, bagus, ramah }\end{array}$ \\
\hline $\mathrm{T}^{\wedge} \mathrm{T}$ & Nangis, mata males, menangis, pingsan & Lucu, bete, sedih, shock banget, cengeng \\
\hline$\sim^{\wedge} \cdot \wedge v$ & Senyum, piss, senang..menari hula-hula, damai & $\begin{array}{l}\text { Lebai, lucu, bahagia, riang, cinta damai, } \\
\text { bercanda, ramah }\end{array}$ \\
\hline$\wedge \wedge \mathrm{a}$ & $\begin{array}{l}\text { Malu-malu, garuk-garuk, senyum canggung, } \\
\text { bingung, berpikir, bingung }\end{array}$ & $\begin{array}{l}\text { Grogi, memaklumi, sedikit bingung, ragu, } \\
\text { sesuatu yang aneh, heran, malu-malu }\end{array}$ \\
\hline
\end{tabular}

Sumber: Hasil pengolahan data pengamatan dan wawancara bulan Maret-Juli 2012

Data tabel 3 dapat menunjukkan bahwa sebagian besar simbol emotikon yang dipertukarkan facebookers dalam interaksi di Facebook memiliki makna yang bersifat individu atau otonom. Walaupun ada beberapa simbol yang memiliki kesamaan makna atau antara makna dan kesan mereka pertukarkan. 
Perbedaan makna dari sebuah simbol (emotikon) yang sama menunjukkan simbol itu bebas digunakan oleh manusia sekaligus membuktikan bahwa makna sebuah tanda atau simbol bersifat arbitrer (sewenang-wenang) dan makna sebuah simbol yang dilekatkan facebookers untuk menunjukkan sesuatu yang ditampilkan. Penggunaan simbol dalam interaksi menguatkan prinsip komunikasi sebagai proses simbolik. Manusia dalam interaksinya membutuhkan simbol atau penggunaan lambang seperti kata Langer (dalam Mulyana, 2009: 92).

Jika dicermati, saya sepakat dengan catatan Nellis bahwa makna bisa berubah pada pengguna tertentu. Sedikitnya ada empat simbol emotikon yang digunakan informan terdapat pada Gambar 1, yaitu simbol emotikon :D (laughing), :) (happy), ;) (winking), dan :* (kiss). Selain itu, simbol emotikon yang digunakan dalam interkasi merupakan hasil produksi para facebookers. Makna dan kesan yang tercipta juga bersifat kontekstual. Artinya, sebuah simbol hampir dimaknai secara berbeda oleh facebookers. Sehingga satu simbol memiliki banyak makna. Merujuk pemikiran Piliang (2010: xli), keragaman makna suatu simbol atau setiap facebookers bebas mengekpresikan diri melalui simbol yang ia produksi, menciptakan penanda-penanda individual, mengembangkan bentuk-bentuk unik, dan menampilkan identitas tak terbatas, maka model semacam ini disebut dengan bazar semiotika. Karena cara-cara seperti itu tidak ditemukan di dalam ruang sosial nyata dan Facebook menjadi semacam ruang kebebasan semiotik luar biasa.

Simbol tidak lagi menunjukkan hasil konvensi, tetapi menjadi produksi pribadi. Makna dan kesan terkadang dipertukarkan. Ada tujuh karakter tandatanda (gambar, foto, simbol, karakter, avatar) di dalam cyberspace termasuk
Facebook, yaitu, tanda kreatif, multiplisitas tanda, tanda ironik, tanda anonim, tanda atau penanda mengapung, tanda simulasi, dan tanda skizofrenia (Piliang, 2010: xliii-xlv). Munculnya simbol emotikon lain di luar simbol yang ditampilkan Nellis merupakan contoh dari tanda kreatif. Individu atau kelompok dapat mengembangkan tanda, simbol, dan citra sendiri, sebab cyberspace menyediakan ruang untuk itu. Misalnya, simbol emotikon $\backslash\left({ }^{\wedge} \mathrm{o}^{\wedge}\right) /, \quad \mathrm{b}^{\wedge} \mathrm{d}, \sim^{\wedge} .^{\wedge} \mathrm{v}$, atau $\mathrm{T}^{\wedge} \mathrm{T}$ yang dikembangkan secara kreatif.

Di samping tanda kreatif, karakter tanda ironik juga diproduksi sebagai simbol yang dipertukarkan dalam interaksi. Nellis mencontohkan simbol emotikon :,( bermakna "menangis." Informan mempertukarkan simbol emotikon $\mathrm{T}^{\wedge} \mathrm{T}$ yang bermakna "menangis," "mata males," dan "pingsan." Simbol emotikon ini, selain menjadi tanda kreatif juga ironik. Dilihat dari kesan yang dipahami, kesan "lucu" yang dibangun pada simbol emotikon $\mathrm{T}^{\wedge} \mathrm{T}$ menjadi tidak cocok dengan kesan lain yang dibangun seperti "menangis," begitu pula dengan maknanya yang cenderung negatif. Banyaknya makna dan kesan yang dilekatkan facebookers pada simbol emotikon membuat simbol itu menjadi tanda anonim sekaligus tanda atau penanda mengapung. Disebut tanda anonim, sebuah tanda dapat memerankan sebuah peran yang dipilih facebookers melalui kesan yang ia bangun. Contohnya, simbol emotikon ;D yang terkesan "genit," tetapi juga terkesan "gembira." Sedangkan menjadi tanda atau penanda mengapung, karena hampir semua orang dapat mengklaim simbol untuk dimaknai sesuai konteks dan kepentingan mereka.

\section{Interaksi di Dunia Virtual Facebook}

Penjelasan di atas mengukuhkan pandangan tentang masyarakat simbolik 
yang tercipta dari moda komunikasi padat teknologi. Melalui rekayasa teknologi digital, realitas virtual hadir dalam bentuk simbolik. Simbol memiliki peran penting dalam dunia virtual, karena masyarakat atau komunitas virtual hanya bisa eksis bila ia mampu mengelola karakter tandatanda (gambar, foto, simbol, karakter, avatar) yang ada di dalamnya dan perwujudannya melalui pemanfaatan berbagai tanda (simbol). Melalui simbol, realitas sosial tersubstitusi ke dalam realitas virtual yang membentuk individu, komunitas, relasi, dan interaksi.

Realitas sosial dalam dunia virtual adalah sebuah paradoks. Misalnya, individu yang ditampilkan terlihat nyata, tetapi sesungguhnya menyembunyikan individu itu secara hakiki. Permainan simbol akan menampilkan beragam individu dengan kesan yang berbedabeda. Tanda-tanda realitas (sign of the real) atau citra realitas (image of the real) menutupi kenyataan sedemikian rupa sehingga antara tanda dan realitas, model dan kenyataan tidak dapat lagi dibedakan (Piliang, 2010: 41). Hal ini menggambarkan bagaimana tanda atau simbol memiliki kemampuan menutupi sebuah kenyataan dan mampu mengaburkan batas antara kenyataan (real) dan artfisial (virtual).

Memahami interaksi di Facebook dari perspektif interaksi simbolik sebenarnya membutuhkan perluasan kajian dibanding sebelumnya yang menekankan kajian pada interaksi manusia di dunia nyata. Menurut Ritzer dan Goodman (2008: 315) "pakar interaksionis didesak untuk lebih khusus lagi memusatkan perhatian pada teknologi komunikasi dan peralatan teknologi dan pada cara-cara teknologi itu menghasilkan realitas dan menggambarkan realitas itu." Dari pendapat ini dapat dipahami bahwa interaksi yang terjadi di Facebook merupakan fenomena teknologi komunikasi yang menghasilkan realitas sekaligus menggambarkan realitas itu sendiri melalui simbol. Setidaknya terdapat tiga gagasan penting untuk dihubungkan dalam memahami realitas vitural (Facebook) pada sebuah kajian, yakni simbol, interaksi, dan komunikasi. Menghubungkan ketiga gagasan itu yang cenderung diabaikan oleh interaksionisme simbolik seperti dikemukakan Denzin. Karena menurutnya "interaksionisme simbolik seharusnya lebih besar lagi perannya dalam studi kultural ketimbang di masa lalu" (Ritzer dan Goodman, 2008: 315).

Dalam konteks penelitian ini, saya mencoba menghubungkan ketiga gagasan di atas yang dilihat dari perspektif interaksi simbolik dengan menekankan pada persoalan pengelolaan kesan simbolik di ruang virtual Facebook sebagai panggung interaksi para penggunanya. Simbol adalah elemen penting dalam dunia virtual Facebook, sebab melalui simbol itu realitas dinyatakan atau ditampilkan. Signifikansi keberadaan simbol-simbol di Facebook salah satunya sebagai media presentasi diri virtual facebookers. Melalui simbol ini pula peran dimainkan oleh facebookers dalam interaksinya.

Berdasarkan pengalaman facebookers, menjalin silaturahim, berinteraksi dan berkomunikasi menjadi alasan penting mengapa mereka menjadi facebookers. Alasan ini bukan hanya sekedar menggambarkan bagaimana teknologi komunikasi menciptakan dan menggambarkan realitas, tetapi juga menggambarkan pengaruh komputer pada sikap dan perilaku manusia. B.J. Fogg menjelaskan:

Computers weren't initially created to persuade; they were built for handling data - calcuating, storing, and retrieving. But computers have migrated from research labs onto desktops and into everyday life, 
they have become more persuasive design. Today computers are taking on variety of roles as persuaders, including roles of influence that traditionally were filled by teachers, coaches, clergy, therapists, doctors, and salespeople, among other. We have entered an era of persuasive technology, of interactive computing systems designed to change people's attitude and behavior (Fogg, 2003: 1).

Penjelasan Fogg memberi pemahaman bahwa fungsi komputer saat ini bukan sekedar alat penghitung, penyimpan, dan memanggil data. Tetapi telah mengambil peran sebagai pembujuk dan memasuki era teknologi persuasif. Teknologi persuasif adalah sistem komputasi interaktif yang dirancang untuk mengubah sikap dan perilaku masyarakat. Lain halnya dengan Ihde yang memandang kehadiran teknologi dalam kehidupan manusia membawa perubahan pengalaman dan persepsi manusia. Ihde mengemukakan ada dua jenis persepsi manusia, yakni mikropersepsi dan makropersepsi. Mikropersepsi terkait dengan persepsi manusia Ada-di-dalam-dunia yang mengalami gerakan, persepsi dan emosi langsung melalui tubuh dan semua indra. Artinya, pengalaman manusia tentang dunia dialami langsung melalui diri sendiri. Sementara makropersepsi sebaliknya, persepsi manusia diperoleh melalui struktur atau budaya di mana manusia berada. Di antara kedua persepsi itu terletak dimensi ketiga, yaitu dimensi teknologi (Lim, 2008: 82-83).

Dalam konteks komunikasi, tekonologi komputer dan internet menjadi bahasan khusus CMC. Thurlow dkk. (2004: 35-36) mengemukakan pertanyaan penting dalam konsep CMC adalah bagaimana orang menggabungkan teknologi ke dalam interaksi sosial mereka dan bagaimana orang berinteraksi melalui atau dengan cara teknologi. Konsep ini menunjukkan peran komputer sebagai sebuah aktivitas manusia. Pertukaran simbol di Facebook memberi gambaran bagaiamana komputer dan jaringan internet berperan penting bagi aktivitas penggunanya secara virtual. Bila mengamati kesan simbolik di Facebook, maka pemikiran Erving Goffman tentang pengelolaan kesan (impression management) menjadi rujukan. Kunci pemikiran Goffman tentang dramaturgi adalah diri sebagai aktor dan audien, tempat pertunjukan atau panggung, dan pengelolaan kesan yang terdiri dari jarak peran, stigma, dan kerangka. Kesan simbolik yang terbangun dari pemahaman facebookers terhadap simbol yang mereka pertukarkan dalam interaksi menunjukkan peran yang mereka mainkan di Facebook. Facebook menjadi panggung depan para facebookers. Sementara dunia nyata menjadi panggung belakang mereka.

Secara khusus pengelolaan interaksi facebookers di dunia virtual Facebook dilakukan melalui dua tahapan. Tahap pertama, melalui perangkat teknologi interaktif, facebookers berinteraksi dengan diri simboliknya. Pada tahap kedua, interaksi sesama facebookers yang diwakili oleh interaksi visual dalam perangkat teknologi interaktif. Setiap tahap interaksi didukung tiga cara dasar yang dimiliki produk komputasi ketika teknologi interaktif beroperasi, yaitu komputer sebagai alat untuk meningkatkan kemampuan, sebagai medium untuk memberikan pengalaman, dan sebagai aktor sosial untuk menciptakan hubungan (Fogg, 2003: 2325). Dari tiga cara tersebut dipahami bagaimana facebookers menggunakan atau menanggapi setiap interaksi yang terjadi.

Interaksi tahap pertama adalah pengelolaan diri simbolik facebookers. Dimulai dari membuat email sampai pada 
membuat dan mengelola akun Facebook adalah bentuk pengelolaan diri simbolik fecebookers. Secara ringkas hal itu menunjukkan fungsi komputasi yang berperan sebagai alat (tool) kepanjangan tubuh dan mendekatkan jarak sekaligus berperan sebagai media simbolik, karena informasi diri yang disampaikan menggunakan berbagai simbol (misalnya, teks, gambar atau ikon). Ketika facebookers berinteraksi dengan diri simboliknya, maka panggung yang ia gunakan adalah panggung depan yang bersifat nyata (real) dan diri fisik yang berada di panggung belakang bersifat virtual. Interaksi antardiri ini memiliki jarak peran antara facebookers dengan perangkat teknologi interaktif. Jarak peran bukan hanya ditandai oleh kedekatan fisik melalui indra penglihatan melainkan ditandai oleh kedekatan pikiran (mind) dan rasa (sense) terhadap diri simbolik yang dihadapi (lihat gambar $3)$.
Interaksi antara diri fisik dan diri simbolik menciptakan hubungan kebertubuhan yang dipengaruhi oleh hubungan manusia dan teknologi dalam memandang dunia seperti ungkap Ihde. Secara fenomenologi hubungan ini menjadi relasi intensional diri facebookers. Relasi ini dalam pandangan Michael Kaye (1994:10-11) tentang manajemen komunikasi dapat dipahami sebagai komponen intrapersonal. Interaksi antardiri (fisik dan simbolik) akan menghasilkan pengetahuan dan pemahaman facebookers tentang dirinya. Sehingga pengelolaan diri (selfmanagement) dapat ia capai. Melalui interaksi ini, kesan yang terbentuk baru pada tahap kesan facebookers terhadap diri virtual atau konsep diri yang tercipta adalah penilaian terhadap diri sendiri melalui simbol yang digunakan. Tahap selanjutnya adalah interaksi antarfacebookers diwakili oleh interaksi diri simbolik (visual).

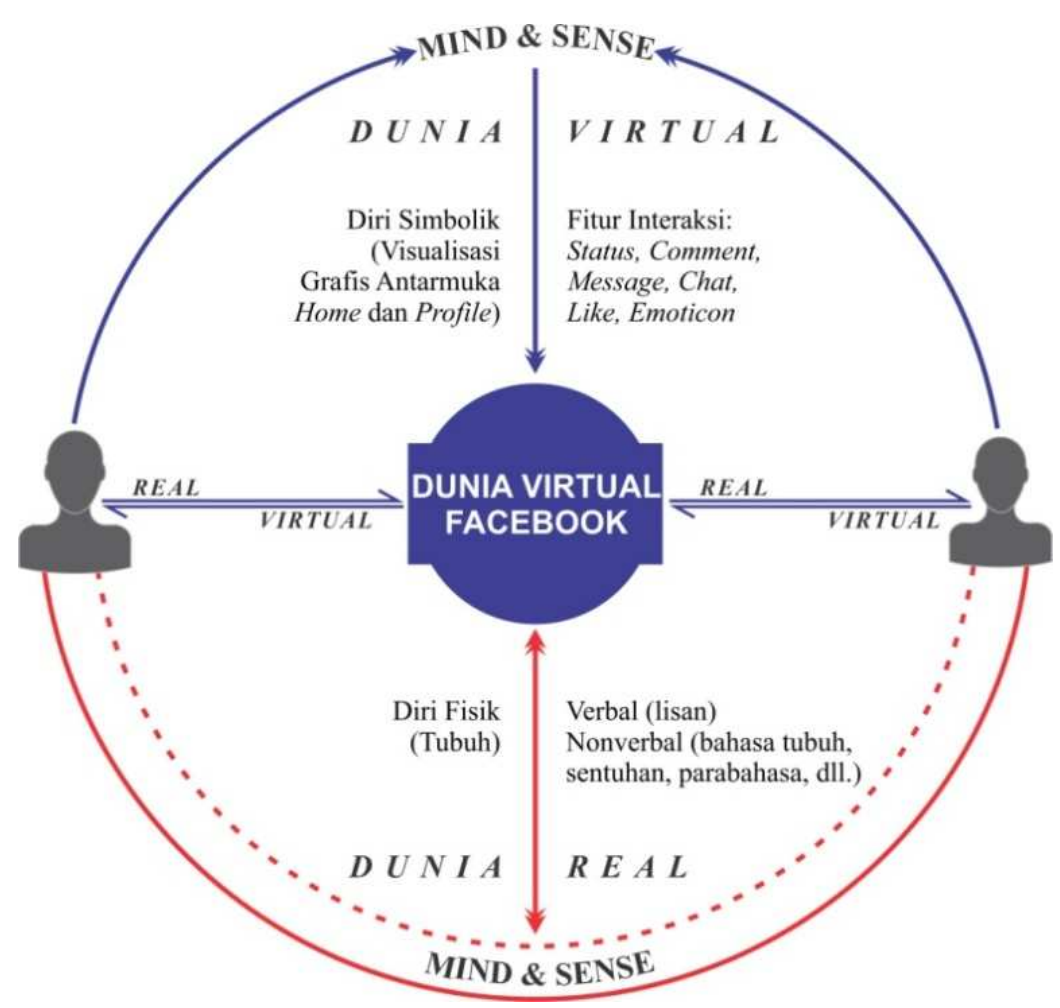

Bagan 1. Model Interaksi di Dunia Virtual Facebook 
Menurut DeVito (2001: 60), selain penghargaan diri (self-esteem), dalam sebuah hubungan dan komunikasi interpersonal dibutuhkan konsep diri (self-concept), kesadaran diri (selfawareness), dan pengungkapan diri (selfdisclosure). Di dunia virtual Facebook, konsep diri, kesadaran diri, pengungkapan diri, dan penghargaan diri sangat ditentukan oleh penggunaan, pemaknaan, dan pemahaman facebookers terhadap berbagai simbol yang mereka pertukarkan. Dimensi teknologi yang menghubungkan mikropersepsi dengan makropersepsi kata Ihde (dalam Lim, 2008: 83) akan menciptakan pengalaman teknologi atau lazim disebut hubungan kebertubuhan (embodiment relation) manusia mengalami dunia-kehidupan melalui alat atau instrumen.

Hal ini berarti, melalui hubungan kebertubuhan antara diri fisik dan diri simbolik akan membangun keyakinan facebookers terhadap diri simbolik sebagai representasi dari diri fisiknya. Selain itu, kesadaran dan pengungkapan diri atas diri simbolik juga dilakukan facebookers. Khusus untuk pengungkapan diri disesuaikan dengan pengaturan yang dilakukan facebookers pada akun Facebook miliknya. Dari seluruh facebookers informan hanya terdapat satu facebookers yang tidak mengungkap identitas dirinya secara detail karena khawatir terjadi penyalahgunaan data pribadi atau kata Debatin dkk. (2009) sebagai privasi online.

Di dunia nyata, setiap facebookers dapat menjalin hubungan langsung dengan facebookers lain (lihat garis tegas warna merah) atau dapat menjalin hubungan satu sama lain setelah terjadi pertemanan di Facebook (lihat garis putus-putus warna merah). Tentu hal ini terjadi bila didasari oleh pikiran dan rasa yang dialami facebookers saat berinteraksi melalui Facebook. Dalam Facebook, diri dipresentasikan (ditampilkan) melalui grafis antarmuka (interface) Home dan Profile. Ikon foto profil menjadi diri yang hidup (aktif) di dunia virtual Facebook. Jika di dunia nyata para facebookers berinteraksi menggunakan bahasa verbal (lisan) dan nonverbal (bahasa tubuh, sentuhan, para bahasa, dll), maka di Facebook mereka berinteraksi menggunakan bahasa visual dengan memanfaatkan simbol verbal (tulisan) dan isyarat nonverbal (emotikon).

Di sini dapat dipahami bahwa Esensi interaksi yang terjadi di Facebook adalah interaksi visual. Melalui interaksi visual, para facebookers membangun hubungan di dunia virtual. Hubungan yang tercipta bisa berbeda antara hubungan di dunia virtual dengan hubungan di dunia nyata. Tetapi, hubungan di dunia virtual dapat menjadi awal pertemanan para facebookers di dunia nyata. Dari hasil pengamatan dan wawancara, interaksi para facebookers di Facebook cukup intens dan akrab. Namun demikian, ada di antara para facebookers yang tidak saling mengenal sebelumnya, bahkan sampai penelitian ini selesai dilaksanakan, beberapa informan belum pernah bertatap muka langsung. Para facebookers yang memiliki hubungan interpesonal di dunia nyata akan mengukuhkan kembali hubungan itu di dunia virtual dengan menjalin pertemanan. Hal sebaliknya juga terjadi, beberapa facebookers mengukuhkan hubungan interpesonalnya setelah berteman melalui Facebook.

\section{Pengelolaan Kesan Simbolik}

Esensi segala aktivitas di dunia virtual ialah aktivitas simbolik. Diri hadir secara simbolik dan interkasi terjadi secara simbolik. Simbol menjadi unsur utama dari segala tindakan facebookers. Jika diri dan interkasi terjadi secara simbolik, maka kesan yang tercipta adalah 
kesan simbolik. Untuk melihat bagaimana kesan simbolik tercipta, model berikut ini akan menggambarkan pengelolaan kesan simbolik yang dilakukan facebookers.

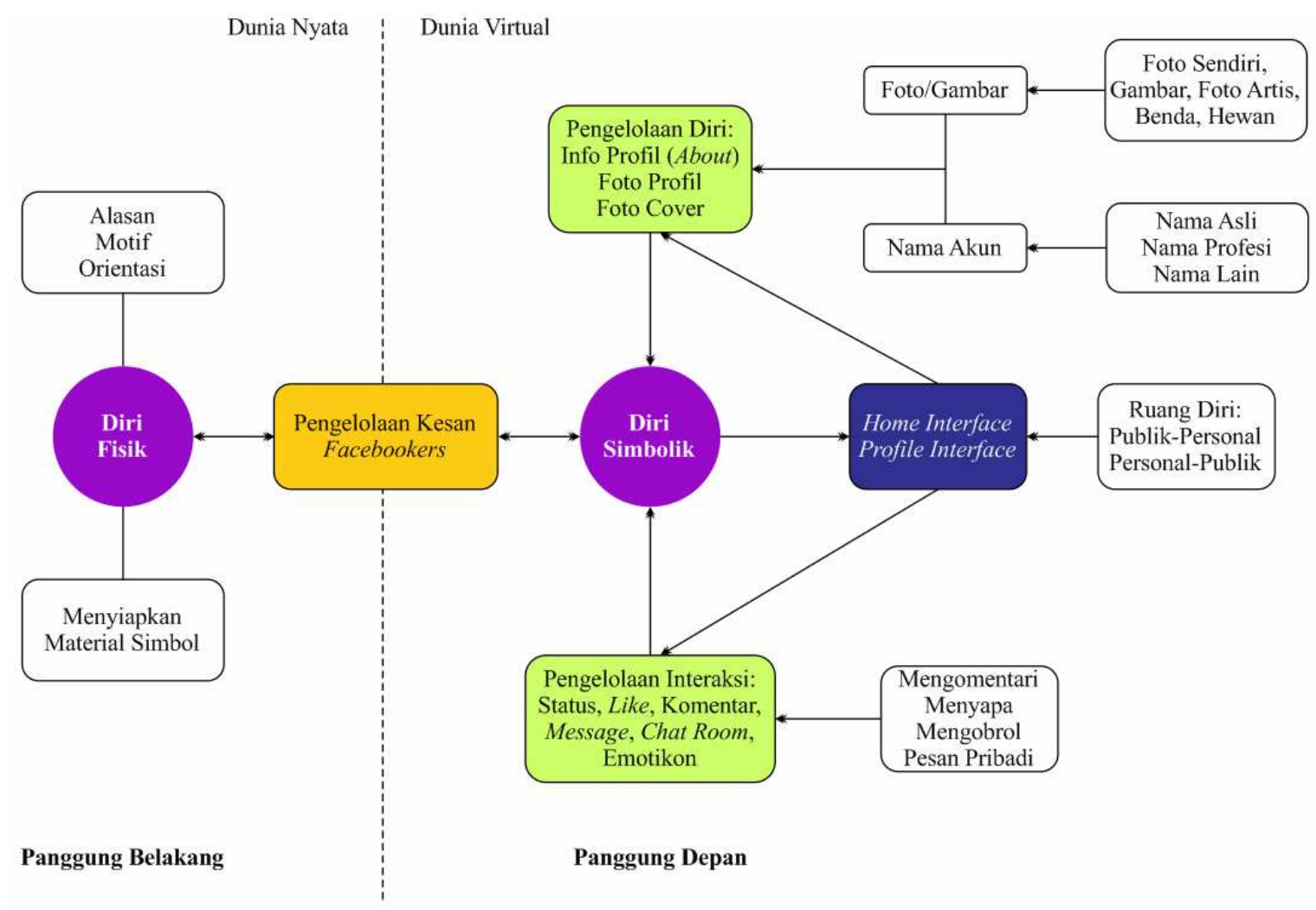

\section{Bagan 2. Model Pengelolaan Kesan Simbolik di Facebook}

Mengacu pada model di atas, pengelolaan kesan facebookers dilakukan melalui diri fisik dan diri simbolik. Kedua diri tersebut memiliki peran sendirisendiri tetapi saling mendukung satu sama lain walaupun keberadaannya di dunia yang berbeda (nyata dan virtual) dan memiliki hubungan timbal balik. Diri fisik facebookers yang berada di dunia nyata dalam konsep dramaturgi dapat dipahami sebagai diri yang memainkan peran di panggung belakang dan diri simbolik yang berada di dunia virtual memainkan peran di panggung depan. Aktivitas di panggung belakang menjelaskan bagaimana facebookers menyiapkan peran bagi diri simboliknya.

Alasan, motif, dan orientasi merupakan unsur-unsur penting yang menentukan peran apa yang akan dimaikan di panggung depan (Talani, 2013: 225). Dari ketiga unsur itu, kemudian facebookers menentukan apa yang akan mereka persiapkan untuk penampilannya di panggung depan. Umumnya yang dipersiapkan adalah materi yang mendukung perannya di panggung depan. Misalnya, membuat status, mengomentari, mempublikasi foto atau karya-karya yang mereka buat dan sebagainya. Tindakan facebookers di panggung belakang bersifat dinamis dan bergantung pada apa yang akan mereka respon sebagai timbal balik dari diri yang berada di panggung depan. Jarak peran antardiri hanya sebatas jarak antara facebookers dengan perangkat yang mereka gunakan untuk mengakses diri simboliknya. Oleh karena itu, tindakan tersebut saya sebut dengan pengelolaan 
diri, karena relasi esksitensial yang terbangun dari relasi intensionalitas subjek (diri fisik) dengan objek visual (diri simbolik).

Dari relasi eksistensial memudahkan diri simbolik memainkan perannya di panggung depan. Pengelolaan diri dan pengelolaan interaksi dihasilkan dari permainan peran intrapersonal dan peran interpersonal. Grafis antarmuka Home dan Profile menjadi setting yang mendukung peran facebookers di panggung depan atau disebut dengan ruang diri publik-personal dan ruang diri personal-publik (lihat Talani, 2013: 174). Kenyataan ruang diri ini dapat dipahami sebagai kerangka dalam pandangan Goffman. Di mana Goffman (dalam Ritzer dan Goodman, 2008: 304) melihat kerangka berfungsi mengorganisir pengalaman facebookers dan membimbing tindakannya baik individual atau kolektif. Pengelolaan informasi profil, foto profil, dan foto cover adalah pengalaman pertama yang diorganisir oleh facebookers sebagai bentuk kerangka pengelolaan diri simbolik. Ada dua indentitas utama diri simbolik yang terkait dengan diri fisik, yaitu nama akun dan foto/gambar yang digunakan dalam profil/cover.

Umumnya identitas yang digunakan para facebookers di panggung depan sesuai dengan identitasnya di panggung belakang atau identitas yang mendukung profesinya. Identitas itu yang membangun pemahaman facebookers terhadap diri simbolik melalui kerangka rujukan yang diketahui atau dibayangkan. George Gonos menjelaskan bahwa sebagian besar kerangka adalah peraturan atau hukum yang mengatur interaksi dan biasanya tak disadari. Penggunaan tanda-tanda yang dihubungkan dengan diri dan pengalaman yang mengiringi aktivitas facebookers di panggung depan adalah aturan-aturan yang mendefinisikan cara menafsirkan tanda-tanda seperti pendapat Gonos
(Ritzer dan Goodman, 2008: 304). Melalui kerangka ini kemudian terbentuk kesan dan kepercayaan terhadap keberadaan diri simbolik dan diri inilah yang melakukan berbagai aktivitas.

Aktivitas mengomentari, menyapa, mengobrol maupun mengirim pesan pribadi adalah bentuk pengelolaan interaksi yang memanfaatkan fitur-fitur yang tersedia di Facebook. Misalnya, fitur status, fitur komentar, fitur message, atau fitur chat room. Berbagai interaksi dalam Facebook pada hakekatnya terjadi dalam diri simbolik baik interaksi intrapersonal maupun interaksi interpersonal. Sehingga bentuk interaksi semacam ini melampaui interaksi di dunia nyata. Dari kenyataan ini tentu membawa dampak pada pemahaman tentang bentuk komunikasi sebagai sarana untuk berinteraksi. Di dunia nyata, bentuk komunikasi intrapersonal adalah komunikasi dengan diri-sendiri seperti berpikir dan komunikasi ini menjadi landasan bagi komunikasi interpersonal dan komunikasi lainnya (Mulyana, 2009: 80). Hal ini berbeda dengan bentuk komunikasi di Facebook. Fitur status misalnya, dapat dipahami sebagai salah satu fitur komunikasi intrapersonal dalam diri simbolik, sedangkan fitur-fitur lainnya bisa berfungsi sebagai fitur komunikasi interpersonal maupun komunikasi yang lain termasuk komunikasi massa dan komunikasi publik bergantung jumlah orang yang terlibat dalam aktivitas komunikasi.

Jadi, esensi pengelolaan kesan di Facebook dilakukan individu yang dihasilkan dari relasi intensional diri fisik (subjek) yang eksis di panggung belakang (dunia nyata) dengan diri simbolik (objek visual) yang eksis di panggung depan (dunia virtual). Pengendalian interaksi terjadi secara individual melalui diri simbolik yang berada di dunia virtual dan dikontrol oleh diri fisik yang berada di 
dunia nyata. Kesan yang dibangun bukan semata-mata melalui diri, tetapi juga melalui simbol yang dipertukarkan selama interaksi khususnya emotikon yang merupakan isyarat nonverbal facebookers.

\section{Penutup}

\section{Kesimpulan}

Sosial media sebagai media interaksi masyarakat masa kini telah menghilangkan kendala ruang dan waktu berinteraksi. Setiap orang dapat berinteraksi kapan saja dan di mana saja sepanjang ia terus terkoneksi ke dalam jaringan internet atau kehidupan keduanya (online) terus berlangsung. Dengan dukungan GUI, daya tarik sosial media semakin memikat. Fitur-fitur yang berbasis GUI telah memudahkan pengguna memahami perintah di sosial media sekaligus mengatur bagaimana mereka berkomunikasi melalui fitur-fitur itu.

Facebook merupakan salah satu sosial media yang popular karena didukung oleh fitur-fitur interaktif dengan kecepatan feedback yang instan. Ketersediaan simbol emotikon memudahkan pengguna Facebook mengungkapkan ekspresinya sebagai isyarat nonverbal. Manun demikian, para facebookers dapat menciptakan simbol emotikon sendiri dan makna simbol itu sangat kontekstual bergantung pada makna yang dilekatkan pada simbol itu. Kedinamisan makna sebuah simbol mencerminkan kemampuan facebookers mempertukarkan (memproduksi, meng- gunakan, dan memaknai) simbol dalam interaksi. Simbol bisa dikembangkan secara kreatif, ironik, maupun anonim atau mengambang. Ketika simbol dipertukarkan bukan saja menghasilkan makna, tetapi juga menghasilkan kesan terhadap penggunanya. Meskipun makna dan kesan sering dipertukarkan.

Masyarakat simbolik yang tercipta dari moda komunikasi padat teknologi telah menjadikan simbol berperan penting dalam dunia virtual termasuk Facebook. Individu, komunitas, relasi, dan interaksi, semuanya direpresentasikan melalui simbol. Diri yang direpresentasikan dalam Facebook dipahami sebagai diri simbolik dan menjadi bagian dari diri fisik. Diri simbolik seolah menjadi kepanjangan dari diri fisik. Melalui diri simbolik itu facebookers membangun hubungan dan berinteraksi satu sama lain. Melalui model di atas dapat diketahui bagaimana esensi interaksi dan pengelolaan kesan simbolik di Facebook. Pemahaman dan pengelolaan diri dan kesan dibentuk oleh relasi eksistensial yang terbangun dari relasi intensionalitas subjek (diri fisik) dengan objek visual (diri simbolik). Sehingga esensi dari interaksi di dunia virtual (Facebook) adalah interaksi visual. 


\section{DAFTAR PUSTAKA}

Adrianto, E. dan B. Q-Anees, 2007. Filsafat Ilmu Komunikasi. Bandung: Simbiosa Rekatama Media.

Awl, D. 2011. Facebook Me!: A Guide to Socializing, Sharing, and Promoting on Facebook. Second Edition. Berkeley: Peachpit Press.

Boeree, C.G. 2009. Personality Theories: Melacak Kepribadian Anda Bersama Psikolog Dunia. Terj. Inyiak Ridwan Muzir. Jogjakarta: Prismasophie.

Creswell, J.W. 1998. Qualitative Inquiry and Research Design Choosing Among Five Traditions. Thousand Oaks London New Delhi: Sage Publication.

Debatin, B., J.P. Lovejoy, A.K. Horn, dan B.N. Hughes. 2009. "Facebook and Online Privacy: Attitudes, Behaviors, and Unintended Consequences." dalam Journal of Computer-Mediated

Communication. October 2009 Volume 15, Issue 1, Pages 83-108. Dari situs http://onlinelibrary.wiley.com/d oi/10.1111/ jcmc.2009.15.issue1/issuetoc. Diakses tanggal 12 November 2010 pukul 20.00 WIB.

DeVito, J.A. 2001. The Interpersonal Communication Book. Ninth Edition. New York: Longman.

Fogg, B.J. 2003. Persuasive Technology: Using Computers to Change What We Think and Do. San Francisco: Morgan Kaufmann Publisher.
Kaye, M. 1994. Communication Management. Australia: Prentice Hall.

Kuswarno, E. 2009. Metodologi Penelitian Komunikasi Fenomenologi: Konsepsi, Pedoman, dan Contoh Penelitian. Bandung: Widya Padjadjaran.

Lim, F. 2008. Filsafat Teknologi: Don Ihde Tentang Dunia, Manusia, dan Alat. Yogyakarta: Kanisius.

Mitra, A. 2010. Digital Communications: From E-mail to the Cyber Community. New York: Chelsea House Publisher.

Mulyana, D. 2008. Metodologi Penelitian Kualitatif: Paradigma Baru Ilmu Komunikasi dan Ilmu Sosial Lainnya. Bandung: Rosda.

\section{Suatu Pengantar. Bandung: Rosda.}

Muntaha, A. 2011. Berpisah-Menyatu dan Berbagi Ruang Rindu di Media Baru: Pengalaman Komunikasi Online Tiga Nettie-Family Indonesia dalam Hamid, F. dan H. Budianto (eds). Ilmu Komunikasi: Sekarang dan Tantangan Masa Depan. 2011. Jakarta: Kencana. Hal. 479-506.

Nellis, K.B. 2004. Technology and Social Change: The Interactive Media Environment dalam Baldwin, J.R., S.D. Perry, dan M.A. Moffitt (eds). 2004. Communication Theories for Everyday Life. USA: Pearson Education, Inc. Hal. 244258. 
Piliang, Y.A. 2010. Post-realitas: Realitas Kebudayaan dalam Era Postmetafisika. Yogyakarta: Jalasutra.

Ritzer, G. dan D.J. Goodman. 2008. Teori Sosiologi Modern Edisi Keenam. Terj. Alimandan. Jakarta: Kencana.

Siregar, A. 2006. "Teori-Teori Media." dalam Bahan Ajar Program Studi Kajian Budaya dan Media. Yogyakarta: Sekolah Pascasarjana UGM.

Sosiawan, E.A. 2001. "Kajian Internet Sebagai Media Komunikasi Dalam Fungsi Mengirim dan Menerima Pesan Bagi Penggunanya," Tesis Megister Ilmu Komunikasi. Bandung: Program Pascasarjana UNPAD.
Talani, N.S. 2013. Fenomena Pengelolaan Kesan Facebookers Dalam Akun "Funco Comics": Studi Fenomenologi Tentang Pengelolaan Kesan Pengguna Situs Jejaring Sosial Facebook (Facebookers) Dalam Akun Pecinta Komik "Funco Comics". Tesis Magister Ilmu Komunikasi. Bandung: Program Pascasarjana UNISBA.

Thurlow, C., L. Lengel, dan A. Tomic. 2004. Computer Mediated Communication: Social Interaction The Internet. London: Sage Publication.

Zaphiris, P. dan C.S. Ang. 2010. Social Computing and Virtual Communities. Boca Raton: CRC Press. 